\title{
Methylen tetrahydrofolate reductase enzyme gene C677T and A1298C mutations in primigravida with first trimester missed abortion: cross-sectional study
}

\author{
Nermeen Mohamed Hefila*
}

Department of Obstetrics and Gynecology, Faculty of Medicine, Alexandria University, El Shatby Medical Campus, Alexandria, Egypt

Received: 04 January 2021

Accepted: 04 February 2021

\section{*Correspondence:}

Dr. Nermeen Mohamed Hefila,

E-mail: nermeenptsbasem81@gmail.com

Copyright: (c) the author(s), publisher and licensee Medip Academy. This is an open-access article distributed under the terms of the Creative Commons Attribution Non-Commercial License, which permits unrestricted non-commercial use, distribution, and reproduction in any medium, provided the original work is properly cited.

\begin{abstract}
Background: This work aimed to correlate between MTHFR C677T and A1298C genes (methylenetetrahydrofolate reductase) mutation and first trimester missed abortion in primigravida to identify pregnant ladies who need anticoagulation therapy to improve pregnancy outcome. The conducted study was a cross-sectional study. Data were collected from females recruited from EL Shatby hospital, Alexandria, Egypt. The present study was done on 40 primigravida females recruited from EL Shatby hospital.

Methods: All participating women were primigravida in their first trimester with missed abortion. Blood specimens were collected from all cases involved in the study for DNA extraction and genotype analysis based on PCR and reverse hybridization. The mutations studied are the MTHFR C667T and A1298C genes. Main outcome measures: The MTHFR C667T mutations in our study is not significantly related to abortion in primigravida while MTHFR A1298C mutations prevalence were appeared significantly have a relation to abortion.

Results: In the current study, the prevalence of MTHFR A1298C mutations was in $52.5 \%$ of cases, with homozygosity in $15 \%$ of cases and heterozygosity in $37.5 \%$ of cases. However, the total prevalence of the MTHFR C667T gene mutations was $30 \%$ of cases only and all are heterozygous. Four cases were prevalent with combined thrombophilia (MTHFR C677T and A1298C) in the participating cases. Finally, the number of individuals were assessed for each of the gene mutations based on of homozygous or heterozygous. No homozygous cases were detected for MTHFR C667T gene mutation.

Conclusions: In this current study, there is an association between miscarriage and thrombophilia.
\end{abstract}

Keywords: MTHFR A1298C, Missed abortion, MTHFR C677T, Primigravida, Thrombophilia

\section{INTRODUCTION}

Pregnancy is associated with increase in coagulation factors leading to hypercoagulable state in pregnancy, a reduction in naturally occurring anticoagulants, and impairment of fibrinolysis. The advantage of these changes is thought to be stabilization of placentation and reduction in post-partum blood loss. ${ }^{1}$

Since 1965 , studies have been made to identify the inherited thrombophilic disorders that promote hypercoagulability (inherited thrombophilia). These include the methylenetetrahydrofolate reductase (MTHFR) and prothrombin mutations. ${ }^{2}$

The American college of obstetricians and gynecologists (2013) believes that there is no a direct link between some types of thrombophilia and adverse pregnancy outcomes in general, and abortion in particular. ${ }^{3}$

Pregnancy losses were divided into first trimester clinical, second trimester and preclinical abortions. ${ }^{4}$ 
It is debate whether a mutation in the gene encoding MTHFR, an enzyme involved in homocysteine metabolism, increases the risk of thromboembolism. ${ }^{5}$

FVL carriage has been shown to increase the early-onset hypertensive disorders with pregnancy and sever PET in pregnancy, severe placental insufficiency and fetal growth restriction. ${ }^{6}$

Pro-thrombophilic factors also are considered as one of the major causes of RPL. In fact, some genetic mutations of prothrombin (FII G 20210A), factor FVL, and MTHFR, C677T and A1298C genes were associated with RPL as they disturb normal placental development leading to fetal growth retardation, accidental hemorrhage, and therefore abortions or stillbirth. ${ }^{7}$

Another cause of abortion is inherited thrombophilia following mutation of factor $\mathrm{V}$ gene G1691A (Leiden mutation) and prothrombin gene (G20210A mutation). These mutations are well studied and their test is part of the diagnostic investigations of RPL. ${ }^{8}$

The most common causes of inherited thrombophilia are mutations in genes encoding MTHFR C667T and A1298C, factor V Lieden, prothrombin (factor II), factor VII, and plasminogen activator inhibitor, while protein $\mathrm{C}$, protein $\mathrm{S}$ and ant thrombin deficiency are less common. ${ }^{9}$

To find a correlation between MTHFR mutant carrier state and RPL would have significant implications for clinical practice and for screening for MTHFR C667T and A1298C mutation and targeted thromboprophylaxis in affected women. ${ }^{10}$

\section{METHODS}

\section{Study population}

This study was carried out on 40 primigravida's who attended Elshatby maternity university hospital, Alexandria, antenatal clinic. The age of subjects was above 18 years and below 35 years. All subjects had missed abortion from the $7^{\text {th }}$ week \pm 1 day to the $13^{\text {th }}$ week +6 days with a history of positive fetal cardiac activity that had stopped suddenly.

\section{Methods}

All the patients in the study were subjected to: detailed history taking, thorough clinical examination, fetal viability assessment by ultrasound and gestational age, and finally, blood samples were collected from all pregnant ladies enrolled in the study for DNA extraction, and genotype analysis. MTHFR C667T and A1298C gene mutations were tested using PCR and reverse-hybridization. The detection of homozygous and heterozygous gene mutations, as well as, the co-expression of mutations was determined.

\section{Statistical analysis of the data}

Data were fed to the computer and analyzed using IBM SPSS software package version 20.0. (Armonk, NY: IBM Corp). ${ }^{11}$ Qualitative data were described using the number and percent. Quantitative data were described using range (minimum and maximum), mean, standard deviation, median, and interquartile range (IQR).

\section{RESULTS}

The study reveals that, the mean age of patients was $24.23 \pm 3.39$ years, (range 18.0-34.0 years). The gestational age recorded by the ultrasound at the time of blood sampling ranged from 8.14-13.71 weeks with a mean of $10.9 \pm 1.59$ weeks. All the laboratory test results are illustrated in Figure 1.

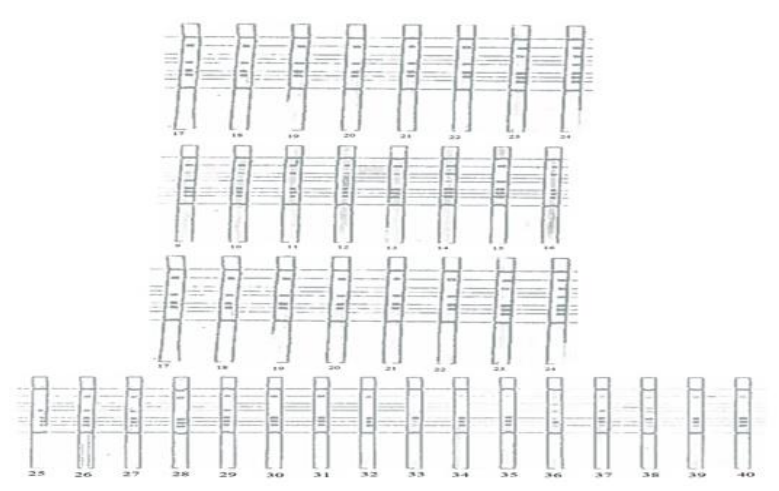

Figure 1: The results of laboratory test.

Figure 2 demonstrates the assessed prevalence of thrombophilia polymorphisms in the studied cases: according to MTHFR A1298C mutations only, the prevalence was in 17 cases $(42.5 \%)$, while MTHFR C667T mutation only prevalence was in 8 cases only (20.0\%). It was observed that $10 \%$ (4 cases) were combined MTHFR A1298C and C667T mutations, while, $27.5 \%$ (11 cases) were normal.

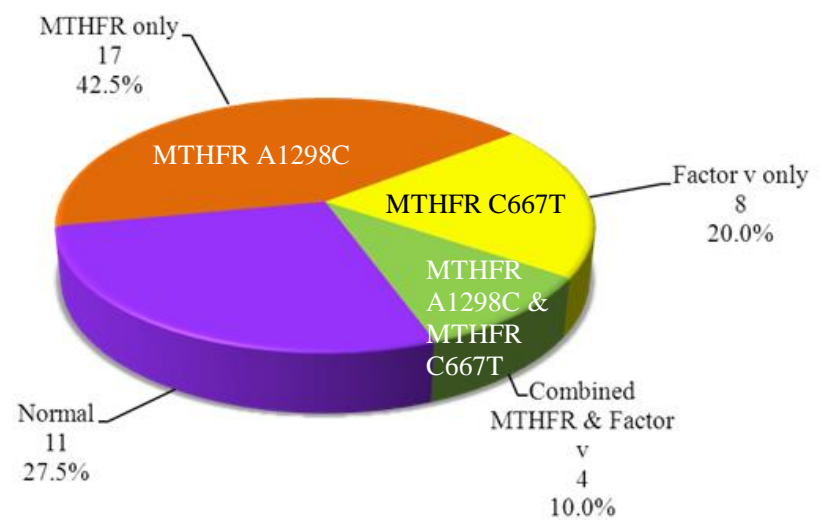

Figure 2: Distribution of the studied cases according to MTHFR A1298C and MTHFR C667T $(n=40)$. 
The number of cases without MTHFR A1298C gene mutations was 19 cases $(47.5 \%)$. While the number of cases with MTHFR A1298C mutations was 21 cases (52.5\%). It was observed that 15 cases out of the 21 cases (37.5\%) with MTHFR A1298C mutations were heterozygous. While 6 cases only out of 21 cases (15\%) with MTHFR A1298C mutations were homozygous. The number of cases without MTHFR C667T mutations was 28 cases $(70.0 \%)$. While the number of cases with MTHFR C667T mutations was 12 cases (30.0\%). It was observed that all cases with MTHFR C667T mutations were heterozygous $(37.5 \%)$, and there were no homozygous cases between the studied cases.

\section{The distribution of the studied cases according to MTHFR A1298C gene mutation and gestational age by the US}

There was no case with MTHFR A1298C gene mutation between 7-8 weeks of gestations. While there were 4 cases with MTHFR A1298C gene mutation between 8-9 weeks of gestations (10\%), 3 cases were heterozygous and 1 case was homozygous. There were 5 cases with MTHFR A1298C gene mutation between 9-10 weeks of gestations $(12.5 \%), 3$ cases were heterozygous and 2 cases were homozygous. While there were 2 cases with MTHFR A1298C gene mutation between 10-11 weeks of gestations $(5 \%)$ and both were heterozygous. There was there were 6 cases with MTHFR A1298C gene mutation between 11-12 weeks of gestations (15\%), 4 cases were heterozygous and 2 cases were homozygous. While there were 2 cases with MTHFR A1298C gene mutation between 12-13 weeks of gestations (5\%) and both were heterozygous. Finally, there were 2 cases with MTHFR A1298C gene mutation between 13-14 weeks of gestations (5\%) and 1 case was heterozygous and the other was homozygous (Table 1).

\section{Regarding distribution of the studied cases according to MTHFR C667T gene mutation and gestational age by the US.}

There was no case with homozygous MTHFR C667T mutation in the studied cases. There was no case with MTHFR C667T gene mutation in the studied cases between 7-8 weeks of gestations. While there was one case with MTHFR C667T gene mutation between 8-9 weeks of gestations, and one case between 9-10 weeks of gestations $(2.5 \%)$ for both. There was there were two cases with MTHFR C667T gene mutation between 10-11 weeks of gestations (5\%), 3 cases were between 11-12 weeks of gestations $(7.5 \%)$. While there were 2 cases with MTHFR C667T gene mutation between 12-13 weeks of gestations (5\%), and 3 cases were between 13 14 weeks of gestations $(7.5 \%)$ (Table 2$)$.

Table 1: Distribution of the studied cases according to MTHFR A1298C and gestational age by the US ( $n=40$ ).

\begin{tabular}{|c|c|c|c|c|c|c|c|c|}
\hline \multirow{3}{*}{ Ultrasound } & \multicolumn{6}{|c|}{ MTHFR } & \multirow{3}{*}{$\chi^{2}$} & \multirow{3}{*}{${ }^{M C} \mathbf{P}$} \\
\hline & \multicolumn{2}{|c|}{ Normal } & \multicolumn{2}{|c|}{ Heterozygous } & \multicolumn{2}{|c|}{ Homozygous } & & \\
\hline & No. & $\%$ & No. & $\%$ & No. & $\%$ & & \\
\hline $7 w-8 w$ & 0 & 0.0 & 0 & 0.0 & 0 & 0.0 & - & - \\
\hline $8 w-9 w$ & 1 & 2.5 & 3 & 7.5 & 1 & 2.5 & 2.076 & 0.340 \\
\hline $9 w-10 w$ & 4 & 10 & 3 & 7.5 & 2 & 5.0 & 0.733 & 0.777 \\
\hline $10 w-11 w$ & 2 & 5 & 2 & 5.0 & 0 & 0.0 & 0.639 & 1.000 \\
\hline $11 w-12 w$ & 5 & 12.5 & 4 & 10.0 & 2 & 5.0 & 0.340 & 1.000 \\
\hline $12 w-13 w$ & 4 & 10. & 2 & 5.0 & 0 & 0.0 & 1.176 & 0.602 \\
\hline $13 w-14 w$ & 3 & 7.5 & 1 & 2.5 & 1 & 2.5 & 1.037 & 0.679 \\
\hline Total & 19 & 47.5 & 15 & 37.5 & 6 & 15.0 & & \\
\hline
\end{tabular}

$\chi^{2}$ : Chi-square test MC: Monte Carlo, $\mathrm{p}$ : $\mathrm{p}$ value for comparing between the three categories

Table 2: Distribution of the studied cases according to MTHFR C667T mutation (n=40).

\begin{tabular}{|c|c|c|c|c|c|c|c|c|}
\hline \multirow{3}{*}{ Ultrasound } & \multicolumn{6}{|c|}{ MTHFR C667T } & \multirow{3}{*}{$x^{2}$} & \multirow{3}{*}{ FEP } \\
\hline & \multicolumn{2}{|c|}{ Normal } & \multicolumn{2}{|c|}{ Heterozygous } & \multicolumn{2}{|c|}{ Homozygous } & & \\
\hline & No. & $\%$ & No. & $\%$ & No. & $\%$ & & \\
\hline $7 w-8 w$ & 0 & 0.0 & 0 & 0.0 & 0 & 0.0 & - & - \\
\hline $8 w-9 w$ & 4 & 10.0 & 1 & 2.5 & 0 & 0.0 & 0.291 & 0.590 \\
\hline $9 w-10 w$ & 8 & 20.0 & 1 & 2.5 & 0 & 0.0 & 2.266 & 0.233 \\
\hline $10 w-11 w$ & 3 & 7.5 & 2 & 5 & 0 & 0.0 & 0.272 & 0.627 \\
\hline $11 w-12 w$ & 8 & 20.0 & 3 & 7.5 & 0 & 0.0 & 0.054 & 1.000 \\
\hline $12 w-13 w$ & 3 & 7.5 & 2 & 5 & 0 & 0.0 & 0.272 & 0.627 \\
\hline $13 w-14 w$ & 2 & 5.0 & 3 & 7.5 & 0 & 0.0 & 2.449 & 0.149 \\
\hline Total & 28 & 70.0 & 12 & 30.0 & 0 & 0.0 & & \\
\hline
\end{tabular}

$\chi^{2}$ : Chi-square test FE: Fisher Exact. p: p value for comparing between the three categories 


\section{Comparison between MTHFR A1298C and C667T}

It showed that there was about 19 case with no gene mutation related to the A1298C while about twenty-eight cases with normal MTHFR C667T so cases with normal study related to MTHFR C667T more than case related to MTHFR A1298C. There were about 15 heterozygous cases of MTHFR A1298C gene mutation which more than heterozygous cases with MTHFR C667T which was about 12 cases. There was no case with homozygous mutation related to MTHFRC667T while was there about 6 cases with homozygous related to MTHFR A1298C gene mutation. There was a significant statistical difference between MTHFR A1298C and C667T with p vale $=0.022^{*}$.

\section{The relation between MTHFRA1298C and C667T}

It revealed that there were about 11 cases with no MTHFR A1298C or C667T genes mutation. There were 11 cases of heterozygous gene mutation of MTHFR A1298C and normal MTHFR C667T. There were 6 cases with homozygous gene mutation of MTHFR A1298C while normal C667T. There were 8 cases with heterozygous gene mutation of MTHFR C667T while normal MTHFR A1298C gene. There were 4 cases with heterozygous gene mutations of both the MTHFR A1298C gene and C667T gene. There was no significant statistical difference between MTHFR A1298C and C667T with $\mathrm{p}$ vale $=00.168$

\section{DISCUSSION}

Pregnancy loss (PL) is a common medical problem among reproductive-age women. However, relatively few women having one pregnancy loss experience multiple or recurrent pregnancy loss. ${ }^{12}$ MTHFR A1298C and C667T genes mutations are suggested as being reasons for PL. ${ }^{13} \mathrm{~A}$ study by Rodger et al, addressed the association of inherited thrombophilia with PL in late primigravida, focusing on tests for FVL, and MTHFR. ${ }^{14}$ The main underlying mechanisms of association between inherited thrombophilia and RPL seem to be abnormality of trophoblast differentiation/invasion, and placental thrombosis of the maternal side resulting in placental complications and fetal loss. ${ }^{15}$ However, the relation between thrombophilia and RPL is controversial and data in the literature are inconsistent because of study heterogeneity, potential publication bias, and sequential testing. ${ }^{16}$

This cross-sectional study aimed to investigate the prevalence of thrombophilic gene mutations (MTHFR A $1298 \mathrm{C}$ and $\mathrm{C} 667 \mathrm{~T}$ ) with miscarriage in primigravida to identify pregnant targeted for anticoagulation to improve pregnancy outcome. This study was done on 40 primigravida pregnant women with missed abortion in the first trimester. In the present study, the maternal age was between 18.0 and 34.0 years, with a mean of $24.23 \pm 3.39$ years. While the gestational age was between
8.14-13.71 weeks with a mean of $10.91 \pm 1.59$ weeks. In our study, MTHFR A1298C mutations were present in 21 cases out of 40 participating cases (52.5\%). Several studies reported increasing evidence for a pathogenetic role of MTHFR gene polymorphism A1298C in early PL. ${ }^{17-19}$ On the other hand, other authors found no association stating that MTHFR polymorphisms do not carry any risk for adverse pregnancy outcomes. ${ }^{20,21}$ According to MTHFRC667T gene mutation, it was present in 12 cases out of 40 participating cases (30\%). There is a large studies showing association between maternally inherited thrombophilia and recurrent miscarriage. ${ }^{16,22,23}$ Although most but not all large prospective cohort studies have failed to establish a constant association between inherited thrombophilia and fetal loss. ${ }^{16,24-27}$ The retrospective cohort studies have generally reported a link between MTHFR C667T heterozygosity and fetal loss. ${ }^{28-31}$ This suggests that any association is limited to high-risk populations and is modest. Small case-control or retrospective cohort studies involving heterogeneous populations have frequently reported contradictory results, in part because of the influence of various confounders (e.g., age, obesity) that are often not analyzed appropriately. ${ }^{29,31}$

In our study, there were 4 cases with combined thrombophilia (10\%). Combined thrombophilia included MTHFR A1298C and MTHFR C677T only. Another studies showing the same results that identified combined thrombophilic defects in women with RPL. ${ }^{17,32-34}$ The study by Rozano-Gorelick et al, reported that combined thrombophilia and every combination of mutant thrombophilic genes carries a different risk of thrombosis. ${ }^{32}$ Furthermore, Sarig et al, proposed a scoring system for women with thrombophilia based on four major categories: obstetric history, previous thromboembolic events, family history of thrombosis or gestational vascular complications, and type of thrombophilia. ${ }^{26}$ Combined thrombophilia was given a high score and the total score is calculated by summing up the scores of the four categories. Based upon the score achieved, the pregnancy risk for an individual woman may be stratified into four levels of risk: low $\leq 5$, intermediate (score 6-10), high (score 11-14), and extremely high (score $\geq 15)$. Finally, the number of homozygous and heterozygous individuals were assessed for each of the gene mutations studied. No homozygosity was detected in cases with MTHFR C667T gene mutation cases. However, 6 cases out of 21 cases of MTHFR A1298C gene mutation were homozygous (15\%). A study by Couto et al, reported a low prevalence of homozygotes for FVL and stated that the prothrombotic tendency during pregnancy and the risk of thromboembolic events is increased with antithrombin deficiency and homozygous FVL as single traits. ${ }^{35}$ In fact, the reported prevalence in the general population of FVL homozygotes is less than $1 \%$ with a $2-4 \%$ risk of venous thromboembolism (VTE) per pregnancy increasing to around $17 \%$ in women with a previous history of VTE. ${ }^{36,37}$ However, most large prospective 
cohort studies have failed to establish a consistent association between inherited thrombophilias and adverse pregnancy outcomes. According to recent evidence, screening for inherited thrombophilia in women with a history of recurrent or nonrecurrent fetal loss, abruption, intrauterine growth restriction, or preeclampsia is not recommended. ${ }^{38}$ Moreover, there is a strong evidence that the prophylactic anticoagulation during pregnancy for the prevention of pregnancy adverse outcomes does not improve pregnancy outcome in affected patients. ${ }^{39}$

\section{CONCLUSION}

The prevalence of MTHFRC667T mutations in our study did not appear significantly affect abortion in primigravida. MTHFR A1298C mutations prevalence were appeared significantly have a relation to abortion. There was no significant increase in the prevalence of combined thrombophilia (MTHFR C677T and A1298C). There is an association between some types of thrombophilia and miscarriage, but the absolute risk is small and varies considerably among reports.

\section{ACKNOWLEDGMENTS}

The authors are thankful to the obstetrics and gynecology department, faculty of medicine, Alexandria university.

Funding: No funding sources Conflict of interest: None declared

Ethical approval: The study was approved by the Institutional Ethics Committee

\section{REFERENCES}

1. Jivraj S, Rai R, Underwood J, Regan L. Genetic thrombophilic mutations among couples with recurrent miscarriage. Hum Reprod. 2006;21(5):1161-5.

2. Ormesher L, Simcox L, Tower C, Greer IA. Management of inherited thrombophilia in pregnancy. Womens Health (Lond). 2016;12(4):43341.

3. Cunningham FG. ea Williams Obstetrics. $24^{\text {th }}$ ed: McGraw-hill Education. 2014;350-75.

4. Alhalaki W, Altanoukhi IA, Alhalabi M. The association of activated protein $\mathrm{C}$ resistance (aPCR) with recurrent pregnancy loss in syrian population. Inter J Pharma Sci Rev Res. 2016;38(151):290-5.

5. D'Uva M, Di Micco P, Strina I, Ranieri A, Alviggi C, Mollo A et al. Etiology of hypercoagulable state in women with recurrent fetal loss without other causes of miscarriage from Southern Italy: new clinical target for antithrombotic therapy. Biologics. 2008;2(4):897-902.

6. Bloomenthal D, Von Dadelszen P, Liston R, Magee L, Tsang P. The effect of factor V Leiden carriage on maternal and fetal health. Cmaj. 2002;167(1):48-54.

7. Turki RF, Assidi M, Banni HA, Zahed HA, Karim S, Schulten HJ et al. Associations of recurrent miscarriages with chromosomal abnormalities, thrombophilia allelic polymorphisms and/or consanguinity in Saudi Arabia. BMC Med Genet. 2016;17(1):69.

8. Kacprzak M, Chrzanowska M, Skoczylas B, Moczulska H, Borowiec M, Sieroszewski P. Genetic causes of recurrent miscarriages. Ginekol Pol. 2016;87(10):722-6.

9. Wolski H, Barlik M, Drews K, Klejewski A, Kurzawińska $\mathrm{G}$, Ożarowski $\mathrm{M}$ et al. Contribution of inherited thrombophilia to recurrent miscarriage in the Polish population. Ginekol Pol. 2017;88(7):38592.

10. Sergi C, Al Jishi T, Walker M. Factor V Leiden mutation in women with early recurrent pregnancy loss: a meta-analysis and systematic review of the causal association. Arch Gynecol Obstet. 2015;291(3):671-9.

11. Kirkpatrick LA, Feeney BC. A simple guide to IBM SPSS statistics for version 20.0. Student ed. Belmont, Calif.: Wadsworth, Cengage Learning. 2013.

12. Christiansen OB, Steffensen R, Nielsen HS, Varming K. Multifactorial etiology of recurrent miscarriage and its scientific and clinical implications. Gynecol Obstet Invest. 2008;66(4):257-67.

13. Park WC, Chang JH. Clinical Implications of Methylenetetrahydrofolate Reductase Mutations and Plasma Homocysteine Levels in Patients with Thromboembolic Occlusion. Vasc Specialist Int. 2014;30(4):113-9.

14. Rodger MA, Paidas M, McLintock C, Middeldorp S, Kahn S, Martinelli I et al. Inherited thrombophilia and pregnancy complications revisited. Obstet Gynecol. 2008;112(2 Pt 1):320-4.

15. Poppe K, Velkeniers B, Glinoer D. The role of thyroid autoimmunity in fertility and pregnancy. Nat Clin Pract Endocrinol Metab. 2008;4(7):394-405.

16. Dizon-Townson D, Miller C, Sibai B, Spong CY, Thom E, Wendel G, Jr., et al. The relationship of the factor $\mathrm{V}$ Leiden mutation and pregnancy outcomes for mother and fetus. Obstet Gynecol. 2005;106(3):517-24.

17. Micco PD, D’Uva M. Recurrent pregnancy loss and thrombophilia. Open Atherosclerosis Thrombosis $\mathbf{J}$. 2009;2(1):33-5.

18. Lissak A, Sharon A, Fruchter O, Kassel A, Sanderovitz J, Abramovici H. Polymorphism for mutation of cytosine to thymine at location 677 in the methylenetetrahydrofolate reductase gene is associated with recurrent early fetal loss. Am J Obstet Gynecol. 1999;181(1):126-30.

19. Wouters MG, Boers GH, Blom HJ, Trijbels FJ, Thomas CM, Borm GF et al. Hyperhomocysteinemia: a risk factor in women with unexplained recurrent early pregnancy loss. Fertil Steril. 1993;60(5):820-5.

20. Makino A, Nakanishi T, Sugiura-Ogasawara M, Ozaki Y, Suzumori N, Suzumori K. No association of C677T methylenetetrahydrofolate reductase and 
an endothelial nitric oxide synthase polymorphism with recurrent pregnancy loss. Am J Reprod Immunol. 2004;52(1):60-6.

21. Ren A, Wang J. Methylenetetrahydrofolate reductase C677T polymorphism and the risk of unexplained recurrent pregnancy loss: a meta-analysis. Fertil Steril. 2006;86(6):1716-22.

22. Silver RM, Zhao Y, Spong CY, Sibai B, Wendel G, Jr, Wenstrom K et al. Prothrombin gene G20210A mutation and obstetric complications. Obstet Gynecol. 2010;115(1):14-20.

23. Rodger MA, Hague WM, Kingdom J, Kahn SR, Karovitch A, Sermer M et al. Antepartum dalteparin versus no antepartum dalteparin for the prevention of pregnancy complications in pregnant women with thrombophilia (TIPPS): a multinational open-label randomised trial. Lancet. 2014;384(9955):1673-83.

24. Roque H, Paidas MJ, Funai EF, Kuczynski E, Lockwood CJ. Maternal thrombophilias are not associated with early pregnancy loss. Thromb Haemost. 2004;91(2):290-5.

25. Clark P, Walker ID, Govan L, Wu O, Greer IA. The GOAL study: a prospective examination of the impact of factor $\mathrm{V}$ Leiden and $\mathrm{ABO}(\mathrm{H})$ blood groups on haemorrhagic and thrombotic pregnancy outcomes. $\mathrm{Br}$ J Haematol. 2008;140(2):236-40.

26. Sarig G, Vidergor G, Brenner B. Assessment and management of high-risk pregnancies in women with thrombophilia. Blood Rev. 2009;23(4):143-7.

27. Preston FE, Rosendaal FR, Walker ID, Briet E, Berntorp E, Conard $\mathrm{J}$ et al. Increased fetal loss in women with heritable thrombophilia. Lancet. 1996;348(9032):913-6.

28. Yamada H, Kato EH, Kobashi G, Ebina Y, Shimada S, Morikawa M, et al. Recurrent pregnancy loss: etiology of thrombophilia. Semin Thromb Hemost. 2001;27(2):121-9.

29. Robertson L, Wu O, Langhorne P, Twaddle S, Clark P, Lowe GD et al. Thrombophilia in pregnancy: a systematic review. Br J Haematol. 2006;132(2):17196.

30. Said JM, Higgins JR, Moses EK, Walker SP, Borg AJ, Monagle PT et al. Inherited thrombophilia polymorphisms and pregnancy outcomes in nulliparous women. Obstet Gynecol. 2010;115(1):513.

31. Bouvier S, Cochery-Nouvellon E, Lavigne-Lissalde G, Mercier E, Fabbro-Peray P, Balducchi JP, et al.
Comparative incidence of pregnancy outcomes in thrombophilia-positive women from the NOH-APS observational study. Blood. 2014;123(3):414-21.

32. Rozano-Gorelick A, Papadakis E, Brenner B. Combined thrombophilia and obstetric complications. Open Atheroscl Thromb J. 2009;2(1):38-41.

33. Raziel A, Kornberg Y, Friedler S, Schachter M, Sela BA, Ron-El R. Hypercoagulable thrombophilic defects and hyperhomocysteinemia in patients with recurrent pregnancy loss. Am J Reprod Immunol. 2001;45(2):65-71.

34. Coulam CB, Jeyendran RS, Fishel LA, Roussev R. Multiple thrombophilic gene mutations rather than specific gene mutations are risk factors for recurrent miscarriage. Am J Reprod Immunol. 2006;55(5):360-8.

35. Couto E, Nomura ML, Barini R, Pinto e Silva JL. Pregnancy-associated venous thromboembolism in combined heterozygous factor $\mathrm{V}$ Leiden and prothrombin G20210A mutations. Sao Paulo Med J. 2005;123(6):286-8.

36. Zotz RB, Gerhardt A, Scharf RE. Inherited thrombophilia and gestational venous thromboembolism. Best Pract Res Clin Haematol. 2003;16(2):243-59.

37. Lockwood CJ, Bauer KA. Inherited thrombophilias in pregnancy. UpToDate. 2016.

38. Bates SM, Greer IA, Middeldorp S, Veenstra DL, Prabulos AM, Vandvik PO. VTE, thrombophilia, antithrombotic therapy, and pregnancy: Antithrombotic Therapy and Prevention of Thrombosis, $9^{\text {th }}$ ed: American College of Chest Physicians Evidence-Based Clinical Practice Guidelines. Chest. 2012;141(2):e691S-736S.

39. Bujold E, Gouin K, Cote S. Low-molecular-weight heparin added to aspirin in the prevention of recurrent early-onset pre-eclampsia in women with inheritable thrombophilia: the FRUIT-RCT: a rebuttal. J Thromb Haemost. 2012;10(6):1195.

Cite this article as: Hefila NM. Methylen tetrahydrofolate reductase enzyme gene C677T and A1298C mutations in primigravida with first trimester missed abortion: cross-sectional study. Int J Reprod Contracept Obstet Gynecol 2021;10:836-41. 